\title{
GELIDIALES (RHODOPHYTA) IN THE CANARY ISLANDS: PREVIOUS STUDIES AND FUTURE PERSPECTIVES
}

\author{
Beatriz Alfonso*, Carlos Sangil and Marta Sansón \\ Universidad de La Laguna
}

\begin{abstract}
Gelidiales is a red algae order which belongs to the class Florideophyceae and comprises four genetically recognized families: Gelidiaceae, Gelidiellaceae, Pterocladiaceae and Orthogonacladiaceae. It is a copious order characterized in the Canary Islands by 16 species, some of which are endemic and canopy-forming with populations in unforeseen decline over the last four decades. The aim of this article is to examine all previous studies into the Gelidiales in the Canary Islands, in order to synthesize and demonstrate the relevance of these species to the benthic marine communities of the archipelago. This review also identifies those knowledge gaps that need to be addressed to predict future changes in the marine ecosystems and suggest conservation and/or recovery plans for their populations.
\end{abstract}

KeYwords: canopy-forming species, endemism, Gelidiaceae, Gelidiellaceae, phenology, Pterocladiaceae, herbarium.

GELIDIALES (RHODOPHYTA) EN LAS ISLAS CANARIAS: ESTUDIOS PREVIOS Y PERSPECTIVAS FUTURAS

\section{RESUMEN}

Gelidiales es un orden de algas rojas perteneciente a la clase Florideophyceae que está constituido por cuatro familias reconocidas genéticamente: Gelidiaceae, Gelidiellaceae, Pterocladiaceae y Orthogonacladiaceae. Es un orden numeroso caracterizado en Canarias por 16 especies, algunas de ellas endémicas, formadoras de hábitats y con poblaciones en marcado declive en las últimas décadas. El objetivo de este trabajo es revisar todos los estudios previos publicados sobre Gelidiales en las islas Canarias con el fin de sintetizar y mostrar su protagonismo en las comunidades bentónicas marinas del archipiélago. Esta síntesis también identifica aquellos vacíos de conocimiento que necesitan ser abordados para predecir cambios futuros en los ecosistemas marinos de Canarias y proponer planes de conservación y/o recuperación de sus poblaciones en las islas.

Palabras clave: endemismo, especies formadoras de hábitat, fenología, Gelidiaceae, Gelidiellaceae, Pterocladiaceae, herbario. 


\section{INTRODUCTION}

The order Gelidiales Kylin (Florideophyceae, Rhodophyta) is constituted of numerous macroalgal species inhabiting the world's template regions (Guiry and Guiry 2019). Gelidiales stand out due to their economic interest as a natural source of high-quality agar and agarose, which are mainly used in the food, cosmetic and biotechnology industries (Rao and Kaliaperumal 1983, 1987; Santelices 1987a, b; Fredriksen and Rueness 1989; Armisén 1994; Freile-Pelegrin et al. 1995; Bouzon et al. 2005, 2006; Scariot et al. 2012; Simioni et al. 2014a, b; Boo et al. 2016a; Filipin et al. 2016). Nevertheless, the ecological role of the Gelidiales also makes them stand out among other rhodophytes as there are several canopy-forming and dominant species that harbor high biodiversity and provide important ecosystem services (Juanes and Puentes 1993; Melo and Neushul 1993; Scrosati and Servière-Zaragoza 2000; Mercado et al. 2001; Bouza et al. 2006; Díez et al. 2012; Polifrone et al. 2012; Borja et al. 2013, 2018; Stroobant et al. 2014; Quintano et al. 2014, 2015, 2017, 2018; Schmidt et al. 2015; Alfonso et al. 2017a, 2018; Otaíza et al. 2018).

Amongst the 7262 documented red algae species, approximately 233 belong to the Gelidiales (Guiry and Guiry 2019). These species share with the entirety of the Rhodophyta a combination of specific attributes that outline them as a distinct eukaryotic monophyletic lineage within the super group of Archaeplastida, together with Glaucophyta and green organisms (green algae and terrestrial plants) (Bhattacharya et al. 2004; Adl et al. 2005; Yang et al. 2005, 2016; Burki 2014; Yoon et al. 2010, 2016). The morphological, cytological and reproductive attributes of the Rhodophyta are: (1) accessory pigments named phycobilins [phycoerythrobilin (red) and phycocyanobilin (blue)] that form clusters on the surface of thylakoids; (2) the unstacked thylakoids in the plastid; (3) floridean starch in the cytoplasm; (4) the presence of pit connections (protoplasmic connections) between adjacent cells; (5) triphasic life cycle (gametophyte, sporophyte and carposporophyte) (Figure 1), and (6) complete absence of flagella and centrioles in all life stages (Dixon 1973; Gabrielson et al. 1990; Woelkerling 1990; Graham and Wilcox 2000; Yoon et al. 2006; Verbruggen et al. 2010; Hurd et al. 2014; Yang et al. 2015). However, the order Gelidiales also display a specific set of morphological characters that enable them to be recognized among other red algae: (1) pseudoparenchymatous uniaxial organization, with the axial filament branched in three planes; (2) agar as component of the cell wall; (3) simple covered pit connections; (4) diplohaplophasic life cycle with isomorphic gametophytes and tetrasporophytes; (5) intercalary carpogonia that originates gonimoblast filaments linking nutritive cells after fertilization; (6) transversally divided spermatangia; and (7) a specific spore germination pattern, so-called "Gelidium-type" (Figure 2) (Hommersand and Fredericq 1988).

* Departamento de Botánica, Ecología y Fisiología Vegetal. Universidad de La Laguna, Tenerife, Canary Islands, Spain. Corresponding author, balfonso@ull.es. 
Currently, there are four accepted families in the Gelidiales; Gelidiaceae Kützing (7 genera, 158 species), Gelidiellaceae Fan (2 genera, 27 species), Pterocladiaceae Felicini et Perrone (3 genera, 24 species) and Orthogonacladiaceae Boo, Le Gaillon, Miller et Boo (2 genera, 4 species). Boo et al. (2016b), combining morphological and molecular studies, described the latest family Orthogonacladiaceae and genetically verified the families previously described (Freshwater and Bailey 1998; Perrone et al. 2006; Tronchin and Freshwater 2007). The main attributes used to separate the families are related to carposporophyte development and cystocarp (carposporophyte protected by a pericarp) morphology. Nevertheless, as fertile gametophytes are uncommon in many Gelidiales species, some vegetative diagnostic characters have been proposed owning to the presence of rhizines (internal thick-walled rhizoidal filaments) and the morphology and ontogeny of the attachment system (Perrone et al. 2006). In addition, the location of sporangia also helps to identify some genera (Table 1).

\begin{tabular}{|c|c|c|c|c|}
\hline \multicolumn{5}{|c|}{$\begin{array}{l}\text { TABLE 1. MAIN DIAGNOSTIC MORPHOLOGICAL CHARACTERS OF } \\
\text { THE FAMILIES IN GELIDIALES (ADAPTED FROM BOO et al. 2016A). }\end{array}$} \\
\hline & Gelidiaceae & Gelidiellaceae & Pterocladiaceae & ORTHOGONACLADIACEAE \\
\hline N. ${ }^{\circ}$ species & 167 & 33 & 29 & 4 \\
\hline Branching pattern & $\begin{array}{l}\text { Irregular, alternate } \\
\text { or pinnate }\end{array}$ & $\begin{array}{l}\text { Irregular, disti- } \\
\text { chous or pinnate }\end{array}$ & $\begin{array}{l}\text { Irregular or } \\
\text { pinnate }\end{array}$ & $\begin{array}{l}\text { Irregular or pinnate } \\
\text { nearly in right angle with } \\
\text { main axis }\end{array}$ \\
\hline Rhizines & Present & Absent & Present & Present \\
\hline \multicolumn{5}{|c|}{ REPRODUCTIVE STRUCTURES } \\
\hline $\begin{array}{l}\text { Tetrasporangia } \\
\text { Location }\end{array}$ & Apical sori & Stichidia & Apical sori & Apical or lateral sori \\
\hline Organization & $\begin{array}{l}\text { Irregularly or in } \\
\text { parallel rows }\end{array}$ & $\begin{array}{l}\text { Irregularly, in } \\
\text { parallel or in } \\
\text { V-like rows }\end{array}$ & $\begin{array}{l}\text { Irregularly, in } \\
\text { parallel or in } \\
\text { V-like rows }\end{array}$ & $\begin{array}{l}\text { Irregularly or } \\
\text { in parallel rows }\end{array}$ \\
\hline $\begin{array}{l}\text { Espermatangia } \\
\text { Location }\end{array}$ & Apical sori & $\begin{array}{l}\text { Apical sori or la- } \\
\text { teral and protrude } \\
\text { sori }\end{array}$ & Apical sori & Apical or lateral sori \\
\hline Cystocarps & Bilocular & Unknown & $\begin{array}{l}\text { Unilocular or } \\
\text { ovoid-triangular }\end{array}$ & Unilocular \\
\hline \multicolumn{5}{|l|}{ Prostrate system } \\
\hline Rhizoidal filaments & $\begin{array}{l}\text { Independent forma- } \\
\text { tion. Endogenous }\end{array}$ & $\begin{array}{l}\text { Independent for- } \\
\text { mation. Unicellu- } \\
\text { lar and exogenous }\end{array}$ & $\begin{array}{l}\text { Endogenous } \\
\text { coalescent within a } \\
\text { thick sheath }\end{array}$ & $\begin{array}{l}\text { Extensively branched. } \\
\text { Endogenous coalescent } \\
\text { within a thick sheath }\end{array}$ \\
\hline Haptera & Present & Absent & Present & Present \\
\hline
\end{tabular}

In relation to the vegetative characters, the branching pattern in Gelidiales is irregularly, alternately, distichously or pinnately branched, with some cases the pinnae and pinnules arising at nearly right angles to the parent branch as occurs in the Orthogonacladiaceae (Boo et al. 2016b). Rhizines are only absent in Gelidiellaceae species. Erect axes of all Gelidiales arise from a prostrate system of entangled stolons attached to the substratum, consisting of either independent rhizoidal filaments or complex haptera (Perrone et al. 2006). The Gelidiellaceae attachment 
system consists of independent unicellular rhizoidal filaments arising from stolon superficial cells that remain in open connection with their mother cells. On the contrary, Gelidiaceae, Pterocladiaceae and Orthogonacladiaceae develop a more complex prostrate system with cells of different origin, morphology and function. In these families, rhizoids have an endogenous origin and arise from the cortical cells, whilst the basal cortication of the attachment system originates exogenously and secondarily from superficial cells. Exceptionally, Pterocladiaceae and Orthogonocladiaceae develop a mucilaginous sheath surrounding the rhizoidal filaments (Perrone et al. 2006; Boo et al. 2016b, c, d).

The reproductive structures in Gelidiellaceae are localized in specialized reproductive branchlets named stichidia (Fan 1961; Rico et al. 2002; Perrone et al. 2006; Boo et al. 2016a). The remaining families display tetrasporangia or bisporangia in apical o lateral sori. Gelidiaceae and Pterocladiaceae develop apical sori, whereas Orthogonacladiaceae and Gelidiellaceae may have apical or lateral sori protruding in the latest family. After fertilization the cystocarps grow bilocular and circular in Gelidiaceae with carposporangia emerging on both surfaces of the fertile branch. Aversely, in Pterocladiaceae and Orthogonocladiaceae the cystocarps are unilocular, ovoid or triangular (Santelices and Hommersand 1997). In Gelidiellaceae, the female reproductive structure is unknown (Santelices 1977; Rico et al. 2002; Boo et al. 2016a).

In the Canary Islands occurrence of 16 species of Gelidiales is currently accepted (Afonso-Carrillo 2014; Boo et al. 2016d; Gallardo et al. 2016), some of which are endemic, canopy-forming and with populations that have been declining over the last decades (Sansón et al. 2013; Martínez et al. 2015; Alfonso et al. 2017b). Furthermore, these macroalgae are important primary producers on exposed rocky shores in the islands, so the severe reduction in their populations is of major concern. This article, therefore, aims to highlight the relevance and importance of the Gelidiales to the benthic marine communities in the archipelago by drawing on previous studies into the Gelidiales in the Canary Islands. There exist certain knowledge gaps that will be identified and in combination with conclusions based on previous studies, future changes to the marine ecosystems will be predicted and conservation and recovery plans for their populations suggested.

\section{GELIDIALES BIODIVERSITY IN THE CANARY ISLANDS}

The number of species documented for the Canary Islands has not significantly changed since the first studies on phytobenthos were carried out on the islands (Montagne 1840; Piccone 1884, 1886; Vickers 1896; Børgesen 1927; Lawson and Norton 1971). Børgesen (1927) had already registered 12 of the species, some of which with recently nomenclatural changes. Nowadays, there are 4 species of Gelidiellaceae, 9 Gelidiaceae and 2 Pterocladiaceae (Afonso-Carrillo and Sansón 1999; Afonso-Carrillo 2014; Guiry and Guiry 2019).

Gelidiellaceae is represented by three genera in these islands, Millerella Boo et Boo (M. tinerfensis, M. pannosa), Parviphycus Santelices (P. antipae, P. setaceus) 
and Huismaniella (Huismaniella sp.). Originally, these species were all described as Gelidiella or Echinocaulon (Afonso-Carrillo and Sansón 1999; Guiry and Guiry 2019), although recent phylogenetic studies have assigned them to the new genera Millerella, Parviphycus and Huismaniella (Boo et al. 2016d). Gelidiella tinerfensis was first described based on specimens collected at Puerto de la Cruz (Tenerife) by Seoane-Camba (1977) and considered endemic to the Canary Islands. Recently this species was recognized synonymous with Millerella tinerfensis (Boo et al. 2016d). Gelidiella tenuissima, listed for the Canary Islands by Audiffred (1985), Betancort et al. (1995), Rico et al. (2002) and Gil-Rodríguez et al. (2003), was considered synonymous with Millerella pannosa (as Gelidiella pannosa) by John et al. (2004). Parviphycus antipae was registered in the archipelago in 1992 (Afonso-Carrillo et al. 1992; Sangil et al. 2003; as Gelidiella), while P. setaceus was documented by Afonso-Carrillo et al. (2007). More recently, Boo et al. (2016d) reported a currently unidentified species of Huismaniella from the Canary Islands (Tenerife) as result of their genetic analyses.

Gelidiaceae is represented in the Canary Islands by 9 species of Gelidium J.V. Lamouroux: G. arbuscula, G. canariense, G. corneum, G. crinale, G. microdon, G. pectinatum, G. pusillum, G. spathulatum and G. spinosum (Gallardo et al. 2016). The first species registered in the islands was $G$. arbuscula. The authority of this species is often attributed to Bory. However, it was Børgesen (1927), who published the combination of $G$. arbuscula, including individuals deposited in the Bory Herbarium collected in Tenerife, which coincided with a specimen named G. corneum var. nereideum by Montagne (1840). Despite also being cited in northeast Africa, Price et al. (1988) and later John et al. (2004) agreed on the lack of evidence of that statement, therefore proposing to accept $G$. arbuscula as an endemic species from the Canary Islands.

Gelidium canariense was originally described as $G$. cartilagineum var. canariensis by Grunow in Piccone (1884) based on specimens collected at Puerto de la Cruz (Tenerife) (Afonso-Carrillo 2003b). Afterwards, the entity was referred only as G. cartilagineum (Lawson and Norton 1971) or as G. versicolor (Haroun et al. 1984), until the new combination proposed by Seoane-Camba (1979) as a new endemic species to the Canary Islands [G. canariensis (Grunow in Piccone) Seoane-Camba]. However, the combination $G$. canariensis was not correctly done in accordance with article 33.3 of the ICBN (Greuter et al. 200) hence, Haroun et al. (2002) validated the species as G. canariense (Grunow in Piccone) Seoane-Camba ex Haroun, Gil-Rodríguez, Díaz de Castro et Prud'homme.

Regarding $G$. corneum, this species was included in the catalogues by Price et al. (1988), John et al. (2004), Afonso-Carrillo (2014) and Gallardo et al. (2016), based on the statement made by Børgesen (1927). Nonetheless, Børgesen (1927) did not observe nor collect any specimen in the Canary Islands, thereupon his reference was based both on Montagne's (1840) study (as G. corneum var. capillaceum, now Pterocladiella capillacea) and also upon the Lyngbye herbarium (Price et al. 1988). As a result of this, Børgesen (1927) referred to G. corneum as probably rare. No further references are known about the presence of this macroalga in the archipelago, so it is very likely to be a misidentification. 
The six remaining species of Gelidium were cited in the first phycological studies performed in the Canary Islands. Gelidium crinale, G. pectinatum and G. pusillum were documented by Vickers (1896) from specimens collected in Gran Canaria. Gelidium pectinatum was reported from a single specimen and never identified again. Surprisingly, G. pectinatum has been omitted from the macroalgae lists of the Canary Islands for several decades, probably due to a nomenclatural problem with Gelidium bipectinatum (Furnari et al. 1999; Taskin and Wynne 2013; Andersen 2018), so although this species needs confirmation, we include it in the marine flora of the Canary Islands. Subsequently, Sauvageau (1912) mentioned G. spathulatum and G. spinulosum (now synonymous with G. microdon) as collected in Tenerife. Finally, G. spinosum was recorded for the first time in the Canary Islands in Price et al. (1988). The complex plasticity that characterizes this group of species, together with the seasonal changes, makes difficult to identify correctly based solely on morphological characteristics. Additional morphological, chemical and genetic studies are needed in order to reach a better knowledge of the diversity in this group of macroalgae in the Canary Islands.

Eventually, the family Pterocladiaceae in the Canary Islands is depicted by two species of the genera Pterocladiella (Afonso-Carrillo and Sansón 1999). Santelices and Hommersand (1997) created Pterocladiella to include the species previously assigned to Pterocladia but display cystocarps with nutritive cells around a central axis and carposporangia radially emerging to the cavity. These attributes are absent in Pterocladia. The species type Pterocladiella capillacea was first mentioned by Børgesen (1927) who stated the citation of G. corneum var. capillaceum in Montagne (1840), today synonymous with the aforementioned species. The second species registered in the Canary Islands, Pterocladiella melanoidea was recorded for the first time in Tenerife in the 1990s (Elejabeitia et al. 1992; Pinedo et al. 1992; Reyes et al. 1993) (Table 2). 
TABLE 2. FAMILIES, GENERA AND GELIDIALES SPECIES DOCUMENTED IN THE CANARY ISLANDS. REFERENCES TO EACH SPECIES ARE INCLUDED

\begin{tabular}{|c|c|c|}
\hline FAMILIES AND GENERA & Species & REFERENCES \\
\hline \multirow{9}{*}{$\begin{array}{l}\text { Gelidiaceae } \\
\text { Gelidium } \\
\text { J.V. Lamouroux }\end{array}$} & $\begin{array}{l}\text { G. arbuscula Bory } \\
\text { de Saint-Vincent et } \\
\text { Borgesen }\end{array}$ & $\begin{array}{l}\text { Vickers 1896; Sauvageau 1912; Børgesen 1927; Lawson } \\
\text { and Norton 1971; Haroun et al. 1984; Price et al. 1988; } \\
\text { Pinedo et al. 1992; Afonso-Carrillo and Sansón 1999; } \\
\text { Haroun et al. 2002; Sangil et al. 2003; Gil-Rodríguez } \\
\text { et al. 2003; John et al. 2004; Afonso-Carrillo 2014; } \\
\text { Gallardo et al. 2016. }\end{array}$ \\
\hline & $\begin{array}{l}\text { G. canariense (Grunow) } \\
\text { Seoane-Camba ex } \\
\text { Haroun, Gil-Rodrí- } \\
\text { guez, Díaz de Castro et } \\
\text { Prud'home van Reine }\end{array}$ & $\begin{array}{l}\text { Montagne 1840; Piccone 1884; Sauvageau 1912; Bør- } \\
\text { gesen 1927; Lawson and Norton 1971; Seoane-Camba } \\
\text { 1979; Haroun et al. 1984; Price et al. 1988; Pinedo et al. } \\
\text { 1992; Afonso-Carrillo and Sansón 1999; Haroun et al. } \\
\text { 2002; Sangil et al. 2003; Gil-Rodríguez et al. 2003; John } \\
\text { et al. 2004; Afonso-Carrillo 2014; Gallardo et al. } 2016 .\end{array}$ \\
\hline & $\begin{array}{l}\text { G. corneum (Hudson) } \\
\text { J.V. Lamouroux }\end{array}$ & $\begin{array}{l}\text { Montagne 1840; Børgesen 1927; Price et al. 1988; } \\
\text { Afonso-Carrillo and Sansón 1999; John et al. 2004; } \\
\text { Afonso-Carrillo 2014; Gallardo et al. } 2016\end{array}$ \\
\hline & $\begin{array}{l}\text { G. crinale (Hare ex } \\
\text { Turner) Gaillon }\end{array}$ & $\begin{array}{l}\text { Montagne 1840; Vickers 1896; Sauvageau 1912; Børgesen } \\
\text { 1927; Price et al 1988; Haroun et al. 2002; Gil-Rodríguez } \\
\text { et al. 2003; John et al. 2004; Afonso-Carrillo 2014; } \\
\text { Gallardo et al. } 2016 \text {. }\end{array}$ \\
\hline & G. microdon Kützing & $\begin{array}{l}\text { Montagne 1840; Price et al. 1988; Afonso-Carrillo and } \\
\text { Sansón 1999; Haroun et al. 2002; Gil-Rodríguez et al. } \\
\text { 2003; John et al. 2004; Afonso-Carrillo 2014; Gallardo } \\
\text { et al. } 2016 .\end{array}$ \\
\hline & G. pectinatum Montagne & $\begin{array}{l}\text { Vickers 1896; Børgesen 1927; Gil-Rodríguez and Afon- } \\
\text { so-Carrillo 1981; Price et al } 1988 .\end{array}$ \\
\hline & $\begin{array}{l}\text { G. pusillum (Stackhouse) } \\
\text { Le Jolis }\end{array}$ & $\begin{array}{l}\text { Vickers 1896; Børgesen 1927; Gil-Rodríguez and Afon- } \\
\text { so-Carrillo 1981; Delgado et al. 1984; Audiffred 1985; } \\
\text { Price et al. 1988; Pinedo et al. 1992; Elejabeitia et al. } \\
\text { 1992; Reyes et al. 1994; González-Ruiz et al. } 1995 \text { a, b; } \\
\text { Guadalupe-González et al. 1995; Afonso-Carrillo and } \\
\text { Sansón 1999; Haroun et al. 2002; Aldanondo-Aristizabal } \\
\text { et al. 2003; Gil-Rodríguez et al. 2003; Sangil et al. 2003; } \\
\text { Díaz-Villa et al. 2004; John et al. 2004; Reyes et al. 2005; } \\
\text { Afonso-Carrillo 2014; Gallardo et al. } 2016 \text {. }\end{array}$ \\
\hline & $\begin{array}{l}\text { G. spathulatum (Kützing) } \\
\text { Bornet }\end{array}$ & $\begin{array}{l}\text { Sauvageau 1912; Børgesen 1927; Price et al. 1988; Haroun } \\
\text { et al. 2002; Gil-Rodríguez et al. 2003; John et al. 2004; } \\
\text { Afonso-Carrillo 2014; Gallardo et al. } 2016 .\end{array}$ \\
\hline & $\begin{array}{l}\text { G. spinosum (S.G. Gme- } \\
\text { lin) P.C. Silva }\end{array}$ & $\begin{array}{l}\text { Price et al. 1988; Afonso-Carrillo and Sansón 1999; } \\
\text { Haroun et al. 2002; Gil-Rodríguez et al. 2003; Sangil } \\
\text { et al. 2003; John et al. 2004; Afonso-Carrillo 2014; } \\
\text { Gallardo et al. 2016. }\end{array}$ \\
\hline
\end{tabular}




\begin{tabular}{|c|c|c|}
\hline \multirow{4}{*}{$\begin{array}{l}\text { Gelidiellaceae } \\
\text { Millerella G.H.Boo } \\
\text { et S.M.Boo } \\
\text { Parviphycus Santelices }\end{array}$} & $\begin{array}{l}\text { M. pannosa (Feldmann) } \\
\text { G.H. Boo et L.Le Gall }\end{array}$ & $\begin{array}{l}\text { Audiffred 1985; Price et al. 1988; Pinedo et al. 1992; Ele- } \\
\text { jabeitia et al. 1992; Betancort et al. 1995; Afonso-Carrillo } \\
\text { and Sansón 1999; Haroun et al. 2002; Aldanondo-Aris- } \\
\text { tizabal et al. 2003; Gil-Rodríguez et al. 2003; John et al. } \\
\text { 2004; Santelices 2004; Afonso-Carrillo 2014; Gallardo } \\
\text { et al. 2016; Boo et al. 2016a. }\end{array}$ \\
\hline & $\begin{array}{l}\text { M. tinerfensis (Seoa- } \\
\text { ne-Camba) S.M. Boo et } \\
\text { J.M. Rico }\end{array}$ & $\begin{array}{l}\text { Seoane-Camba 1977; Price et al. 1988; Guadalupe-Gon- } \\
\text { zález et al. 1995; Afonso-Carrillo and Sansón 1999; } \\
\text { Haroun et al. 2002; Rico et al. 2002; Gil-Rodríguez } \\
\text { et al. 2003; Sangil et al. 2003; John et al. 2004; Afon- } \\
\text { so-Carrillo 2014; Gallardo et al. 2016; Boo et al. 2016d; } \\
\text { Woelkerling et al. 2018. }\end{array}$ \\
\hline & $\begin{array}{l}\text { P. antipae (Celan) B. } \\
\text { Santelices }\end{array}$ & $\begin{array}{l}\text { Elejabeitia et al. 1992; Afonso-Carrillo and Sansón } \\
\text { 1999; Haroun et al. 2002; Gil-Rodríguez et al. 2003; } \\
\text { Sangil et al. 2003; John et al. 2004; Santelices 2004; } \\
\text { Afonso-Carrillo 2014; Gallardo et al. } 2016 .\end{array}$ \\
\hline & $\begin{array}{l}\text { P. setaceus (Feldmann) } \\
\text { J. Afonso-Carrillo, } \\
\text { M. Sansón, C. Sangil et } \\
\text { T. Díaz-Villa }\end{array}$ & $\begin{array}{l}\text { Afonso-Carrillo et al. 2007; Afonso-Carrillo 2014; } \\
\text { Gallardo et al. } 2016 .\end{array}$ \\
\hline $\begin{array}{l}\text { Huismaniella } \\
\text { G.H. Boo et S.M. Boo }\end{array}$ & Huismaniella sp. & Boo et al. 2016d \\
\hline \multirow{2}{*}{$\begin{array}{l}\text { Pterocladiaceae } \\
\text { Pterocladiella B.Sante- } \\
\text { lices et Hommersand }\end{array}$} & $\begin{array}{l}\text { P. capillacea (S.G.Gme- } \\
\text { lin) Santelices et Hom- } \\
\text { mersand }\end{array}$ & $\begin{array}{l}\text { Montagne 1840; Piccone 1884, 1886; Vickers 1896; } \\
\text { Børgesen 1927; Delgado et al. 1984; Pinedo et al. 1992; } \\
\text { Elejabeitia et al. 1992; Reyes et al. 1994; Guadalupe-Gon- } \\
\text { zález et al. 1995; Lawson } \text { et al. 1995; Afonso-Carrillo and } \\
\text { Sansón 1999; Haroun } \text { et al. 2002; Gil-Rodríguez et al. } \\
\text { 2003; Sangil et al. 2003; John et al. 2004; Afonso-Ca- } \\
\text { rrillo 2014; Gallardo et al. 2016. }\end{array}$ \\
\hline & $\begin{array}{l}\text { P. melanoidea (Schous- } \\
\text { boe ex Bornet) Santelices } \\
\text { et Hommersand }\end{array}$ & $\begin{array}{l}\text { Pinedo et al. 1992; Elejabeitia et al. 1992; Reyes et al. } \\
\text { 1993; Lawson et al. 1995; Afonso-Carrillo and Sansón } \\
\text { 1999; Haroun et al. 2002; Gil-Rodríguez et al. 2003; } \\
\text { Sangil et al. 2003; John et al. 2004; Rancel 2008; Afon- } \\
\text { so-Carrillo 2014; Gallardo et al. 2016. }\end{array}$ \\
\hline
\end{tabular}

\section{BIOLOGICAL AND MOLECULAR STUDIES OF GELIDIALES IN THE CANARY ISLANDS}

The dominant and habitat forming species Gelidium canariense, G. arbuscula and Pterocladiella capillacea have been the target for most studies performed on the Gelidiales of the Canary Islands due to their important ecological role on the rocky shores. These studies have mainly dealt with the vegetative and reproductive phenology, ecophysiology and genetic diversity of the species (Darias-Rodríguez and Afonso-Carrillo 1986; Sosa and García-Reina 1992, 1993; Sosa et al. 1998; García-Jiménez et al. 1999; Mercado et al. 2001; Bouza, 2002; Rico et al. 2005; Bouza et al. 2006; Domínguez-Álvarez et al. 2011; Polifrone et al. 2012). The other Gelidiales species appear primarily as part of cespitose assemblages, albeit little is known about their relevance to the marine communities of the islands (Rico et al. 2002; Rancel 2008). 
Gelidiales show a Polysiphonia-type life cycle characterized by isomorphic alternation of generations (Figure 1). Diploid sporophytes form sporangia where meiosis occurs to generate haploid spores. After attachment and germination of the spores, they develop into dioecious gametophytes (male and female). Both the sporangia and spermatangia alike are formed in apical or lateral sori. Similarly, carpogonia also arise at terminal ends of branches but they are only evident after fertilization, when they become prominent cystocarps (Chihara and Kamura 1963; Hommersand and Fredericq 1988).

Phenological studies on Gelidium canariense, G. arbuscula and Pterocladiella capillacea show a clear dominance in terms of populations of tetrasporophytes $(\mathrm{T})$ in comparison with female $(\mathrm{F})$ and male $(\mathrm{M})$ gametophytes. In G. canariense, ratios of 3:1:1 (T:F:M) (Darias-Rodríguez and Afonso-Carrillo 1986), 12:3:1 (Polifrone et al. 2012) and 4:1:1 in Tenerife (Alfonso et al. 2017a) and 4:1 (T:F) in Gran Canaria (Lindgren et al. 1998) have been found. In G. arbuscula, a T:G ratio of 7:1 was detected in Tenerife and Gran Canaria (Sosa and García-Reina 1992) and 33:1 in Tenerife (Polifrone et al. 2012), whereas in P. capillacea the ratio was 133:1:1 (T:F:M) in Tenerife (Polifrone et al. 2012) and 14:1 (T:F) in Gran Canaria (Stroobant et al. 2014). These evident differences in tetrasporophyte ratios documented in the literature may be due to changes in temperature and irradiance during the year or site studied. In fact, Stroobant et al. (2014) suggest an important effect of these factors on $P$. capillacea tetrasporophyte ratios.

Studies into spatio-temporal variations in populations of the endemic Gelidium canariense have agreed on the absence of seasonality of fertile individuals. Thus, all life cycle phases can be found throughout the year (Darias-Rodríguez and Afonso-Carrillo 1986; Lindgren et al. 1998; Polifrone et al. 2012; Alfonso et al. 2017a). In Gran Canaria, Betancort and González (1991) characterized a population with individuals more than $15 \mathrm{~cm}$ in length consisting of abundant small individuals (0-5 cm in length), which may suggest a high level of recruitment in the population. More recently, Alfonso et al. (2017a) described for the first time the coexistence of two different morphotypes in $G$. canariense populations. One morphotype is characterized by longer branches with a higher number of apices and occur in fertile (tetrasporophytes and gametophytes) individuals, whereas the other corresponds to smaller and less ramified non-fertile individuals. This study widens the available information about the vegetative and reproductive morphology of this endemic species (Piccone 1884; Børgesen 1927; Seoane-Camba 1979; Rico et al. 2005).

On the other hand, Gelidium arbuscula and Pterocladiella capillacea display a clear seasonality in their life cycles. Fertile female gametophytes of $G$. arbuscula only appear in winter in the Tenerife and Gran Canaria populations, while fertile female and male gametophytes of $P$. capillacea can be found in summer and winter respectively. In both species fertile tetrasporophytes can be observed throughout the entire year (Polifrone et al. 2012; Stroobant et al. 2014). In addition, the cespitose Pterocladiella melanoidea develops female gametophytes year-round according to Rancel (2008) and contrary to previous studies (Fredriksen and Rueness 1990). 
Canopy-forming Gelidiales in the Canary Islands have also been the focus of different physiological studies. Cardell et al. (1977) studied the annual variation of the agar content in Gelidium arbuscula and G. canariense. Agar is a phycocolloid used in food, cosmetic and laboratory industries, which is a natural component of the cell walls and intercellular matrix of Gelidiales and cannot be synthetized in laboratory. These authors determined that the agar content of these Gelidiales increase in July and reaches a maximum in November. Furthermore young individuals have an increase of $20 \%$ in agar content compared with older specimens.

Mercado et al. (2001) studied the effect of dissolved inorganic carbon (DIC) and incident light on the photosynthetic activity of Gelidium canariense, G. arbuscula and Pterocladiella capillacea. Among the different strategies of carbon uptake in macroalgae (Mercado et al. 1997, 1998, 2001; Giordano et al. 2005), Mercado et al. (2001) demonstrated that these species had a low capacity of use $\mathrm{HCO}_{3}{ }^{-}$(DIC) actively from the environment and that the light was a limiting factor to their photosynthetic rates. Populations of $G$. canariense, G. arbuscula and $P$. capillacea inhabit the northern rocky shores of the islands where clouds tend to accumulate the most (Martín et al. 2011), thus, affecting the light incidence to the surface. Furthermore, the northern shores of the islands are characterized by a strong hydrodynamism that allows the water to maintain high $\mathrm{CO}_{2}$ concentrations independently of the light irradiance level. Hence, the adaptation of these species to their environment would favor the uptake of $\mathrm{CO}_{2}$ by diffusion rather than by the active uptake of DIC when the light incidence level is low. However, the specific strategy of carbon acquisition in this species needs particular experiments to confirm this.

The photosynthetic inhibition of Gelidium arbuscula was studied in the Gran Canaria populations under natural conditions by exposing individuals to incident natural light and filtered ultraviolet (UV) radiation (Häder et al. 2001). The photosynthetic ability of macroalgae is determined by the energy associated to UV radiation and photosynthetically active radiation (PAR). However, when this energy exceeds the photochemical demand or dissipation ability of organisms, it is frequently related to photosensitivity, photo-tolerance, photosynthetic damage and photoinhibition (Hanelt and Figueroa 2012; Harb et al. 2018). According to Häder et al. (2001) the PAR values during the experiment reached $2000 \mu \mathrm{mol}^{*} \mathrm{~m}^{-}$ ${ }^{2 *} \mathrm{~s}^{-1}$ in air and $400 \mu \mathrm{mol}^{*} \mathrm{~m}^{-2 *} \mathrm{~s}^{-1}$ at a depth of 4-6 m. The results after 30 minutes of continuous exposition to both PAR and filtered UV radiation revealed permanent damage to the algae. When $G$. arbuscula is exposed only 15 minutes, it is able to recover under sheltered conditions, although it never reaches the same photosynthetic levels. This outcome suggests that emersion periods during low tides are crucial to the survival of this species.

Not only is the incident light, but also the desiccation tolerance a key factor in the distribution and survival of the phytobenthos (Häder et al. 2011; Hawkins et al. 2016). Domínguez-Álvarez et al. (2011) studied the tolerance to emersion in Gelidium canariense, G. arbuscula and Pterocladiella capillacea on the northern shore of Tenerife. The results show a clear effect of desiccation tolerance to vertical 
distribution of these species. The endemic G. canariense, which grows in the upper sublittoral below the other two species, was indeed the most affected after the emersion. In the case of $G$. arbuscula, water loss of the thallus was reduced, although the clumped morphology of this species favors the maintenance of humidity. Lastly, $P$. capillacea demonstrated the fastest rehydration and recovery. This species is distributed worldwide and grows over the other two species in infralittoral pools or in the upper sublittoral, which demonstrates its high adaptability to environmental changes (Domínguez-Álvarez et al. 2011). However, little is known about the combined effect of irradiance and temperature on desiccation tolerance or photosynthesis production predicted under the scenario of climate change.

Recent studies have demonstrated the connection of some volatile compounds to the maturation of tetrasporangia in P. capillacea (García-Jiménez et al. 2013). Various physiological processes related to interspecific competition or reproductive mechanisms in macroalgae imply the emission and/or reception of compounds such as ethylene and dimethyl sulfide (DMS), a biogenic compound with antioxidants and defenses against herbivores (Fink 2007). In G. arbuscula, the effect of different light conditions (white light, red light and dark) on the production of these volatile compounds was studied (Alstyne and Puglisi 2007). The result was that there was no clear response or cellular damage to the algae, even though $G$. arbuscula produced high concentrations of dimethyl sulfide under all light conditions. Nevertheless, the authors admitted the need of further studies to assess the particular function of these compounds in the metabolism of this species.

\section{BIOLOGICAL AND EARLY DEVELOPMENT STUDIES}

General features of the life cycle of Gelidiales are well known since the first detailed descriptions by Kylin (1923). Yet recently, particular attention has been placed upon certain differences among families or even species (Maggs and Rico 1991; Rico et al. 2005; Simioni et al. 2014a; Alfonso et al. 2018). One example is the formation of different types of sporangia and spores in some Gelidiales, despite the typical cruciate tetrasporangia. Rico et al. (2005) described bisporangia along with cruciately, decussately and irregularly divided tetrasporangia in individuals of Gelidium canariense deposited in TFC (Herbarium of Universidad de La Laguna). According to Suneson (1982) in some coralline algae and several other rhodophytes, the bisporangia can produce binucleate haploid bispores or uninucleate diploid bispores, whereas the tetrasporangia generate uninucleate tetraspores. Rico et al. (2001) found in $G$. canariense mature binucleate spores, which in other species of the genus, usually only appear in immature sporangia (Maggs and Rico 1991).

Attachment and germination of diaspores to the substrate are the most critical and vulnerable stages in the life cycle of benthic macroalgae, with their success threatened by several factors (Fletcher and Callow 1992; Brawley and Johnson 1992; Fierst et al. 2005). In Gelidiales, the diaspores are tetraspores and carpospores, and their germination pattern is the so-called Gelidium-type, specific to the order (Chihara and Kamura 1963; Hommersand and Fredericq 1988). García-Jimé- 
nez et al. (1999) developed an axenic cultivation protocol for $G$. canariense from the Canary Islands, so that the species could be exploited as an agar source. After being released, the tetraspores were cultivated in an antibiotic solution for 55 days, after which the formation of rhizoidal filament and the erect axis began. More recently, Alfonso et al. (2018) described in detail the initial stages of the tetraspore development in G. canariense and G. arbuscula and agreed with the Gelidium-type germination pattern (Figure 2). Surprisingly, the spore germination in these species began between 2-4 h after release (Alfonso et al. 2018), nearly $2 \mathrm{~h}$ before other Gelidium species (Simioni et al. 2014a). This behavior could be an adaptive strategy for species that inhabit shores with strong hydrodynamism. Therefore, the faster attachment and germination of the spore would favor the recruitment of their populations. In addition, Gelidiales species also have modular-clonal growth, with new erect axes arising from the perennial attachment system (Santos and Duarte 1996; Hurd et al. 2014). This characteristic, along with the earlier attachment and germination of the spores, would contribute notably to their ability to maintain their populations and even colonize new substrates.

The life history of most of the cespitose Gelidiales is still incomplete. Initially, the absence of gametophytes was considered a diagnostic character in the genus Gelidiella until the first description of spermatangial sori in Gelidiella acerosa (Santelices 1997). Subsequently, Rico et al. (2002) obtained male gametophytes from cultivated tetraspores of Millerella pannosa (as Gelidiella tenuissima) of Gran Canaria. Only plants cultivated at $20^{\circ} \mathrm{C}$ developed spermatangial sori which completely covered both surfaces of the fertile branch. To better understand the biological differences among all cespitose Gelidiales species, further studies and cultivation experiments on their life cycles are needed.

\section{Genetic And Phylogenetic studies}

Genetic studies focusing on Gelidiales of the Canary Islands are scarce. Sosa and García-Reina $(1992,1993)$ analyzed genetic variability by isoenzyme electrophoresis of female gametophytes and tetrasporophytes of Gelidium canariense and G. arbuscula from populations in Tenerife and Gran Canaria. Despite being the first contribution to the knowledge of population dynamics of these dominant species, the number of genes used in the haploid subpopulation (gametophytes) were four times greater than those used in the diploid subpopulation (tetrasporophytes), so the authors suggested a possible bias on the results. With this in mind, Sosa et al. (1998) re-evaluated the previous data and only used the diploid subpopulation. Their results showed that both species differ in their mating systems and patterns of genetic differentiation. Gelidium canariense and $G$. arbuscula had significant differences among populations. However, differences between populations were twice as high in $G$. arbuscula than in $G$. canariense. According to the authors, one possible explanation is that the clonal growth and genetic drift is higher in G. arbuscula and therefore displays different allele frequency in haploid and diploid populations. On the contrary, no significant differences were found between tetrasporophytes and game- 
tophytes allele frequencies in $G$. canariense, concluding that sexual reproduction is the main reproductive system in this species.

Bouza (2002) and Bouza et al. (2006) also contributed to the study of genetic diversity of natural populations of Gelidium canariense. They focus on eight localities of the northern rocky shores of central islands (Tenerife and Gran Canaria) and western islands (La Gomera and La Palma) analyzing random amplified polymorphism DNA (RAPD) marker variation. Their results demonstrated high levels of genetic diversity among populations, contrary to the findings of Sosa and García-Reina (1993), although they do agree on the important role of sexual reproduction to the genetic variability between populations. Furthermore, they established a level of isolation between different islands, albeit only analyzing the genetic variability of female gametophytes. Hence, before stating any conclusions on the population structure and genetic diversity of macroalgae with complex biological cycles, it is important to consider all phases of the life history (Krueger-Hadfield and Hoban 2016).

Several phylogenetic studies of Gelidiales have included species from the Canary Islands. Freshwater et al. (1995) and Tronchin et al. (2002) include DNA material from Gelidium canariense collected in Tenerife and G. pusillum collected and cultivated by Rueness and Fredriksen. Results establish that $G$. canariense belongs to the clade of European Gelidium, while G. pusillum is part of a species-complex together with species of the genera Onikusa, Suhria and Gelidium. At a later date, Boo et al. $(2014,2016 \mathrm{~b})$ analyzed the molecular phylogeny of Gelidiales, including $G$. canariense, based on five genetic markers. Results indicate that $G$. canariense is closely related to G. spinosum, G. attenuatum and G. pulchellum.

The phylogeny of the Gelidiellaceae was also re-analyzed by Boo et al. (2016d), combining morphological and molecular criteria. They proposed a new classification of the family divided into five different groups (Gelidiella, Huismaniella, Parviphycus adnatus, Millerella and Perronella gracilis). A sample from the Canary Islands is referred as Huismaniella sp. exhibiting morphological characteristics very similar to Parviphycus setaceus as described by Afonso-Carrillo et al. (2007). However, according to the authors, DNA analysis of the type material of $P$. setaceus is required in order to confirm the synonymy. This study also concluded that the genetic sequence analyzed by Rico et al. (2002) and identified as GelidieIla tenuissima (currently considered as synonym of Millerella pannosa), is analogue to that of the endemic $M$. tinerfensis. Additional studies are necessary to clarify this species-complex from this archipelago. Finally, Boo et al. (2016d) highlighted the morphological similarity between Parviphycus antipae and the species of Millerella, although genetic analyses are needed to support this.

\section{ECOLOGY, DISTRIBUTION AND CONSERVATION OF GELIDIALES IN THE CANARY ISLANDS}

The first studies into the phytobenthos of the Canary Islands had already observed that the macroalgae communities in the northern exposed coasts of central and western islands were dominated by Gelidium arbuscula and G. canariense. 
Sauvageau (1912) and Lawson and Norton (1971) described each of these populations forming a dense belt on the rocky walls just beneath the yellow band of Treptacantha abies-marina (as Cystoseira abies-marina). According to Sauvageau (1912), the uppermost red-purple belt was characterized by $G$. arbuscula, whereas underneath it developed a thicker and darker band of $G$. canariense, except in abrupt rocky platforms where both species appeared intermingled. Lawson and Norton (1971) also documented this zonation pattern with these species located at the beginning of the sublittoral in northern exposed rocky shores.

The great abundance of Gelidium arbuscula and $G$. canariense in the north of Tenerife (Wildpret et al. 1987) gave rise to its exploitation as a natural resource of agar (Afonso-Carrillo 2003a). Interestingly, the agar obtained from Gelidium is of the highest quality and the only one that can be used in the biotechnology industry to produce culture medium (McHugh 2004; Bixler and Porse 2011; Hurd et al. 2014). Since 1950, local fishermen have collected up to 40-50 tons of dry weight of Gelidium per year from natural populations that were uprooted by waves. Periodically, this material was air-dried and sent to mainland industries until 1960 when this practice was abandoned since the compilation and transport was not economical (Afonso-Carrillo 2003a, b).

The vertical distribution of macroalgae in Puerto de la Cruz ( $\mathrm{N}$ of Tenerife) presented by Lawson and Norton (1971) changed after two decades. New studies highlighted a new red belt characterized by Pterocladiella capillacea, generally located above Gelidium arbuscula or in infralittoral rocky pools (Darias-Rodríguez and Afonso-Carrillo 1986; Betancort and González 1991; Pinedo et al. 1992; Pinedo and Afonso-Carrillo 1994). Nowadays, P. capillacea, G. arbuscula and G. canariense are dominant and canopy-forming species of the rocky upper sublittoral at wave-exposed northern shores of La Palma, La Gomera, Tenerife and Gran Canaria (Figure 3) (Wildpret et al. 1987; Afonso-Carrillo 2003b; Sangil et al. 2004; Rodríguez et al. 2008).

Wildpret et al. (1987) documented the distribution of Gelidium arbuscula and G. canariense in the 1980s. This study indicates the location of the most common macroalgae assemblages of the upper sublittoral in the archipelago, including the communities dominated by these Gelidiales, noted as the G1-G. arbuscula belt and G2-zonated community G. arbuscula, G. canariense and Treptacantha abies-marina (as Cystoseira abies-marina). Twenty years later, Rodríguez et al. (2008a,b) provided data on distribution and population size of $G$. arbuscula and $G$. canariense in different sites of the islands, including a digital cartography of their populations. These studies are of great interest to assess changes occurred throughout the years.

Besides differences in abundance and vertical distribution, recent studies have indicated a reduction in length of Gelidium specimens in the last four decades. The greatest decline is described in G. canariense, whose individuals have decreased from $30 \mathrm{~cm}$ (Seoane-Camba 1979) to less than $20 \mathrm{~cm}$ (Polifrone et al. 2012; Sansón et al. 2013; Alfonso et al. 2017b). Børgesen (1927) described individuals of $14 \mathrm{~cm}$ in $G$. arbuscula, while those studied by Polifrone et al. (2012) were less than 12 $\mathrm{cm}$ long. On the contrary, Pterocladiella capillacea have exhibited similar length over the years, at 9 to $14 \mathrm{~cm}$ (Polifrone et al. 2012; Sansón et al. 2013; Alfonso 
et al. 2017b). The study of herbarium specimens deposited since 1970 until 2015 in TFC (Dpto. Botánica, Ecología y Fisiología Vegetal; Facultad de Ciencias; ULL) and BCM (Dpto. Biología; Facultad de Ciencias del Mar; ULPGC) have demonstrated a significant decline in the individual length and number of reproductive structures in $G$. arbuscula and $G$. canariense. In addition, this trend also correlates significantly with a significant increase in sea surface temperature over the same period. In contrast, these changes are not detected in P. capillacea (Sansón et al. 2013; Alfonso et al. 2017b). Experimental studies are necessary in order to verify the effects of different environmental variables on the growth of these species, variables that are also changing due to climate change. As a result of these sharp changes in morphology and population abundance, $G$. arbuscula and $G$. canariense have been recently considered as "vulnerable species" in the Listado de Especies Silvestres en Régimen de Protección Especial y Catálogo Español de Especies Amenazadas (Orden TEC/596/2019, BOE 2019).

Different studies on intertidal and subtidal communities document several cespitose Gelidiales from the Canary Islands. Gelidium pusillum is one of the most common species in the cespitose assemblages across the archipelago (Elejabeitia et al. 1992; Pinedo et al. 1992; Reyes et al. 1994, 2005; González-Ruiz et al. 1995a, b; Guadalupe-González et al. 1995), whereas Millerella tinerfensis or Pterocladiella melanoidea have been only occasionally reported (Seoane-Camba 1977; Guadalupe-González et al. 1995; Sangil et al. 2003; Rancel 2008) and their real distribution and ecological role on the islands needs further research.

\section{FUTURE PERSPECTIVES ON GELIDIALES}

This review identifies knowledge gaps in the biology and ecology of Gelidiales in the Canary Islands. Certain aspects need further investigation and will help to predict future changes in the diversity, morphology, physiology and ecology of these rhodophytes. This is of grave concern especially with the canopy-forming threatened Gelidiales that are vulnerable to changes, thus, conservation plans and management strategies are necessary in order to recover the populations. The comparison of historical and current data on abundance and distribution of the populations will allow assessment of their conservation status and the extinction risk of the endemic species. The study of the cespitose Gelidiales, of which little is still known, is also important. These overlooked species might play a key role as habitat-forming species in early succession stages when sensitive species decline (Bertolini 2019).

The accurate diversity of Gelidiales species in the Canary Islands is still uncertain. Some species documented to these islands are based on historic and doubtful records (i.e. Gelidium corneum, G. pectinatum, G. sphatulatum, G. spinulosum, G. spinosum). The apparent high morphological plasticity characteristic of some species could indicate new cryptic species that will not be detected unless we combine morphological and molecular techniques in further studies on the Gelidiales of the Canary Islands. 
Regarding the vegetative and reproductive morphology, additional findings are required particularly in reference to the species of Gelidiellaceae whose female gametophytes are missing and their life cycle is still incomplete. The distribution, vegetative and reproductive phenology, spatio-temporal shifts or successful recruitment rates in many Gelidiales are yet to be discovered. This lack of information makes it difficult to foresee the effects of environmental changes on individual and population levels.

To conclude, it is pivotal to improve our knowledge on Gelidiales species from the Canary Islands owing to the fact that some of them contribute to ecosystem services in the archipelago. Others are endemic and vulnerable species (Millerella tinerfensis, Gelidium canariense, $G$. arbuscula) or common species on cespitose macroalgae assemblages at the eastern Atlantic (Gelidium pusillum and Gelidiellaceae), while there are other introduced species distributed worldwide (Pterocladiella capillacea). All these attributes make these species model macroalgae to study and useful tools in order to predict future changes in the marine ecosystems of the Canary Islands.

\section{ACKNOWLEDGMENTS}

This work has been possible thanks to the predoctoral agreement between Universidad de La Laguna and the funding entity CajaSiete granted to B. Alfonso.

\section{AUTHORS CONTRIBUTION}

Conceptualization: BA.

Original draft: BA, MS.

Review and edition of the final draft: all authors. 


\section{REFERENCIAS}

Adl, S.M., Simpson, A.G., Farmer, M.A., Andersen, R.A., Aderson, O.R., Barta, J.R., Bowser, S.S., Brugerolle, G., Fensome, R.A., Frederice, S., et al. 2005. The new higher level classification of eukaryotes with emphasis on the taxonomic of protists. J. Eukaryot. Microbiol. 52: 399-451.

Afonso-Carrillo, J. 2003a. Aprovechamiento industrial de algas marinas canarias para la extracción de agar. Puerto de la Cruz (1951-1966). El Pajar. Cuaderno de Etnografía Canaria 15: 173-184.

Afonso-Carrillo, J. 2003b. Bajíos y algas marinas de Puerto de la Cruz: una historia de la botánica marina en Canarias. Catharum: Revista de Ciencias y Humanidades 4: 14-27.

Afonso-Carrillo, J. 2014. Lista actualizada de algas marinas de las islas Canarias. Informe de la Sociedad Española de Ficología. España. 64 p.

Afonso-Carrillo, J. \& Sansón, M. 1999. Algas, hongos y fanerógamas marinas de las Islas Canarias. Clave analítica. Servicio de Publicaciones Universidad de La Laguna. 254 p.

Afonso-Carrillo, J., Pinedo, S. \& Elejabeitia, Y. 1992. Notes on the benthic marine algae of the Canary Islands. Cryptogamie Algol. 13: 281-290.

Afonso-Carrillo, J., Sansón, M., Sangil, C. \& Díaz-Villa, T. 2007. New records of benthic marine algae from the Canary Islands (eastern Atlantic Ocean): morphology, taxonomy and distribution. Bot. Mar. 50: 119-127.

Aldanondo-Aristizabal, N., Domínguez-Álvarez, S. \& Gil-Rodríguez, M.C. 2003. Diversidad algal asociada a Patella candei candei D’Orbigny, 1840, una lapa en peligro de extinción en la isla de Fuerteventura. Bol. Inst. Esp. Oceanogr. 19: 165-170.

Alfonso, B., Hernández, J.C. \& Sansón, M. 2018. Tetraspore germination of two vulnerable marine algae, Gelidium canariense and G. arbusculum (Rhodophyta, Gelidiales). Bot. Mar. 61: 111-114.

Alfonso, B., SAngil, C. \& Sansón, M. 2017a. Morphological and phenological reexamination of the threatened endemic species Gelidium canariense (Gelidiales, Rhodophyta) from the Canary Islands. Bot. Mar. 60: 543-553.

Alfonso, B., Sansón, M. \& Hernández, J.C. 2017b. Historical morphological changes of three species of Gelidiales. Libro de resúmenes International Phycological Congress. Phycologia 56: 6.

Alstyne, K.L. \& Puglisi, M.P. 2007. DMSP in marine macroalgae and macroinvertebrates: Distribution, function and ecological impacts. Aquat. Sci. 69: 394-402.

Andersen, R.A. 2018. Report of the nomenclature committee for algae: 18. Taxon 67: 437-438.

Armisén, R. 1994. Productos derivados del Gelidium: producción, estructura y aplicaciones. En: Juanes, J.A. and González, S. (eds), Gelidium: de los recursos a las aplicaciones. Diputación General de Cantabria. España. 27 p.

Audiffred, P.A. 1985. Marine algae of El Hierro (Canary Islands). Vieraea 14: 157-183.

Bertolini, C. 2019. Can secondary species maintain a primary role? Consistent inter-regional effects of understory algae on diversity. Marine Biodiversity 49: 841-849.

Betancort, M.J. \& González, M.N. 1991. Estudio preliminar sobre la biología de las poblaciones de Gelidium canariensis (Grunow) Seoane en Gran Canaria. Acta Botánica Malacitana, 16: 51-58. 
Betancort, M.J., González, M.N., Haroun, R., Herrera, R., Soler, E. \& Rodríguez, M.A. 1995. Adiciones corológicas a la flora marina de Canarias. Bot. Macaronésica 22: 75-89.

Bhattacharya, D., Yoon, H.S. \& Hackett, J.D. 2004. Photosynthetic eukaryotes unite: endosymbiosis connects the dots. Bioessays 26: 50-60.

Bixler, H.J. \& Porse, H. 2011. A decade of change in the seaweed hydrocolloids industry. J. Appl. Phycol. 23: 231-235.

$B O E$ (Boletín Oficial del Estado). 2019. Modificación del anexo del Real Decreto 139/2011 para el desarrollo del Listado de especies silvestres en régimen de protección especial y del Catálogo Español de especies amenazadas. Ministerio de Transición Ecológica, Gobierno de España 134: 58611-58615.

Boo, G.H., Kim, K.M. \& Nelson, W.A. 2014. Taxonomy and distribution of selected species of the agarophyte genus Gelidium (Gelidiales, Rhodophyta). J. Appl. Phycol. 26: 1243-1251.

Boo, G.H., Hughey J.R., Miller, K.A. \& Boo, S.M. 2016a. Mitogenomes from type specimens, a genotyping tool for morphological simple species: ten genomes of agar-producing red algae. Sci. Reports 6: 35537.

Boo, G.H., Le Gall, L., Miller, K.A., Freshwater, D.W., Wernberg, T., Terada, R., Yoon, K.J. \& Boo, S.M. 2016b. A novel phylogeny of the Gelidiales (Rhodophyta) based on five genes including the nuclear CesA, with descriptions of Orthogonacladia gen. nov. and Orthogonacladiaceae fam. nov. Mol. Phylogenet. Evol. 101: 359-372.

Boo, G.H., Le Gall, L., Hwang, I.K. \& Boo, S.M. 2016c. Pterocladiella feldmannii sp. nov. and $P$. hamelii sp. nov. (Gelidiales, Rhodophyta), two new species uncovered in Madagascar during the Atimo Vatae Expedition. Cryptogamie Algol. 37: 179-198.

Boo, G.H., Nguyen, T.V., Kim, J.Y., Le Gall, L., Rico, J.M. Bottalico, A. \& Boo, S.M. 2016d. A revised classification of the Gelidiellaceae (Rhodophyta) with descriptions of three new genera: Huismaniella, Millerella and Perronella. Taxon 65: 965-979.

Børgesen, F. 1927. Marine algae from the Canary Islands especially from Teneriffe and Gran Canaria III. Rhodophyceae Part I Bangiales and Nemalionales. Biol. Meddr. 6: 1-97.

Borja, A., Fontán, A. \& Muxika, I. 2013. Interactions between climatic variables and human pressures upon a macroalgae population: implications for management. Ocean Coast. Manage. 76: 85-95.

Borja, A., Chust, G., Fontán, A., Garmendia, J.M. \& Uyarra, M.C. 2018. Long-term decline of the canopy forming algae Gelidium corneum, associated to extreme wave events and reduced sunlight hours, in the southeastern Bay of Biscay. Est. Coast. Shelf. Sci. 205: 152-160.

Bouza, N. 2002. Contribución al conocimiento de las poblaciones naturales de «Gelidium canariense» (Rhodophyta) desde una perspectiva genética y demográfica. Tesis Doctoral. Universidad de Las Palmas de Gran Canaria. España. 323 p.

Bouza, N., Caujapé-Castells, J., González-Pérez, M.A. \& Sosa, P.A. 2006. Genetic structure of natural populations in the red algae Gelidium canariense (Gelidiales, Rhodophyta) investigated by random amplified polymorphic DNA (RAPD) markers. J. Phycol. 42: 304-311.

Bouzon, Z.L. Ouriques, L.C. \& Oliveira E.C. 2005. Ultrastructure of tetraspore germination in the agar-producing seaweed Gelidium floridanum (Gelidiales, Rhodophyta). Phycologia 44: 409-415.

Bouzon, Z.L. Ouriques, L.C. \& Oliveira, E.C. 2006. Spore adhesion and cell Wall formation in Gelidium floridanum (Rhodophyta, Gelidiales). J. Appl. Phycol. 18: 287-294. 
BRAWLEY, S.H. \& JohnSON L.E. 1992. Gametogenesis, gametes and zygotes: an ecological perspective on sexual reproduction in the algae. Br. Phycol. J. 27: 233-252.

Burki, F. 2014. The eukaryotic tree of life from a global phylogenomic perspective. Cold Spring Harb. Perspect. Biol. 6: a016147.

Cardell, C.E., Esteban, C. \& Fernández, L. 1977. Curvas anuales del contenido en agar-agar y aislamiento del D-manitol en dos algas de las Islas Canarias: Gelidium arbuscula Bory y Gelidium cartilagineum (L.), Goill. var. canariensis Grun. Ann. Inst. Bot. A.J. Cavanilles 34: 303-308.

Chinara, M. \& Kamura, S. 1963. On the germination of tetraspores of Gelidiella acerosa. Phycologia, 3: 69-74.

Darias-Rodríguez, J.M. \& Afonso-Carrillo, J. 1986. Reproducción y fenología de Gelidium versicolor (S. Gmel.) Lamouroux (Rhodophyta) en el Puerto de la Cruz (Tenerife). Libro de Resúmenes V Simposio Ibérico del Bentos Marino. Puerto de la Cruz. p. 85.

Delgado, E., González, M.N. \& Jorge, D. 1984. Contribución al estudio de la vegetación ficológica de la zona de Arinaga (Gran Canaria). Bot. Macaronésica 12-13: 97-110.

Díaz-Villa, T., Tronholm, A., Afonso-Carrillo, J. \& Sansón M. 2004. Adiciones a la flora de algas marinas bentónicas de El Hierro (Islas Canarias). Vieraea 32: 167-176.

Díez, I., Muguerza, N., Santolaria, A., Ganzedo, U. \& Gorostiaga, J.M. 2012. Seaweed assemblage changes in the Eastern Cantabrian Sea and their potential relationship to climate change. Estuar. Coast. Shelf Sci. 99:108-120.

Dixon, P.S. 1973. Biology of the Rhodophyta. New York (USA). Hafner Press. 251 p.

Domínguez-Álvarez, S., Rico, J.M. \& Gil-Rodríguez, M.C. 2011. Photosynthetic response and zonation of three species of Gelidiales from Tenerife, Canary Islands. Anales del Jardin Botánico de Madrid 68: 117-124.

Elejabeitia, Y., Reyes, J. \& Afonso-Carrillo, J. 1992. Algas marinas bentónicas de Punta del Hidalgo, Tenerife (Islas Canarias). Vieraea 21: 1-28.

FAn, K.C. 1961. Morphological studies of the Gelidiales. University of California Publications in Botany 32: 315-368.

Fierst, J.L., TerHorst, C.P., Kubler, J.E. \& Dudgeon, S.R. 2005. Fertilization success can drive patterns of phase dominance in complex life histories. J. Phycol. 41: 238-249.

Filipin, E.P., Bouzon, Z.L., Ouriques, L., Pereira, D.T., Braum, F., Schmidt, E.C. \& Simioni, C. 2016. Evaluation of salinity effects on the realese, adhesión and germination of the tetraspores of Gelidium floridanum (Rhodophyta, Florideophyceae). J. Appl. Phycol. 28: 2925-2938.

Fink, P. 2007. Ecological functions of volatile organic compounds in aquatic systems. Mar. Freshw. Behav. Phy. 40: 155-168.

Fletcher, R.L. \& Callow, M.E. 1992. The settlement, attachment and establishment of marine algal spores. Br. phycol. J. 27: 303-329.

Fredriksen, S. \& Rueness, J. 1989. Culture studies of Gelidium latifolium (Grev.) Born et Thur (Rhodophyta) from Norway. Growth and nitrogen storage in response to varying photon flux density, temperature and nitrogen availability. Bot. Mar. 32: 539-546.

Fredriksen, S. \& Rueness, J. 1990. Culture studies on Pterocladia melanoidea (Schousboe ex Bornet) comb. nov. (Gelidiales, Rhodophyta). Phycologia 29: 182-190. 
Freile-Pelegrín, Y., Robledo, D.R. \& García-Reina, G. 1995. Seasonal agar yield and quality in Gelidium canariensis (Grunow) Seoane-Camba (Gelidiales, Rhodophyta) from Gran Canaria, Spain. J. Appl. Phycol. 7: 141-144.

Freshwater, D. \& Bailey, J. 1998. A multigene phylogeny of the Gelidiales including nuclear largesubunit rRNA sequence data. J. Appl. Phycol. 10: 229-236.

Freshwater, D.W., Fredericg, S. \& Hommersand, M.H. 1995. A molecular phylogeny of the Gelidiales (Rhodophyta) based on analysis of plastid rbcL nucleotide sequences. J. Phycol. 31: 616- 632 .

Furnari, G., Cormaci, M. \& Serio, D. 1999. Catalogue of the benthic marine macralgae of the Italian coast of the Adriatic Sea. Bocconea, Palermo, Italia. 218 p.

Gabrielson, P.W., Garbary, D.J., Sommefeld, M.R., Townsend, R.A. \& Tyler, P.L. 1990. Phylum Rhodophyta. In: Margulis, L., Croliss, J.O., Melkonian, M. and Champan, D.J. (eds.) Handbook of Protoctista: The Structure, Cultivation, Habitats and Life Histories of the Eukaryotic microorganisms and their descendants exclusive of Animals, Plants and Fungi. Boston. Jones and Bartlett Pub. 914 p.

Gallardo, T., Bárbara, I., Afonso-Carrillo, J., Bermejo, R., Altamiro, M., Gómez Garreta, A., Barceló Martí, M.C., Rull Lluch, J., Ballesteros, E. \& De la Rosa, J. 2016. Nueva lista crítica de las algas bentónicas marinas de España. Algas 51: 7-52.

García-Jiménez, P., Marina, F.D., Rodrigo, M. \& Robaina, R.R. 1999. Sporulation and sterilization method for axenic culture of Gelidium canariensis. J. Biotechnol. 70: 227-229.

García-Jiménez, P., Brito-Romano, O. \& Robaina, R.R. 2013. Production of volatiles by the red seaweed Gelidium arbuscula (Rhodophyta): emission of ethilene and dimethyl sulfide. J. Phycol. 49: 661-669.

Gil-Rodríguez, M.C. \& Afonso-Carrillo, J. 1981. Catálogo de las algas marinas bentónicas (Cyanophyta, Chlorophyta, Phaeophyta y Rhodophyta) para el Archipiélago Canario. Aula de Cultura de Tenerife. Santa Cruz de Tenerife, España. 47 p.

Gil-Rodríguez, M.C., Haroun, R., Ojeda, A., Berecibar, E., Domínguez, P. \& Herrera B. 2003. División Protoctista. En: Moro, L., Martín, J.M., Garrido, M.J., \& Izquierdo, I. (eds.) Lista de especies marinas de Canarias (algas, hongos, plantas y animales). Consejería Política Territorial y Medio Ambiente del Gobierno de Canarias. pp. 5-23.

Giordano, M., Beardall, J. \& Raven, J.A. 2005. $\mathrm{CO}_{2}$ Concentrating mechanisms in algae: mechanisms, environmental, modulation and evolution. Ann. Rev. Plant Biol. 56: 99-131.

González-Ruiz, S., Reyes, J., Sansón, M. \& Afonso-Carrillo, J. 1995a. Flora marina de Cotillo, noroeste de Fuerteventura (Islas Canarias). Vieraea 24: 13-38.

González-Ruiz, S., Sansón, M. \& Reyes, J. 1995b. Distribución vertical de las algas en el litoral de Cotillo (Noroeste de Fuerteventura, Islas Canarias). Vieraea 24: 39-50.

Guadalupe-GonzÁlez, M.E., Gil-Rodríguez, M.C. \& Hernández-González, M.C. 1996. Flora y vegetación marina de Arrecife de Lanzarote. Fundación César Manrique, Lanzarote. 272 p.

Guiry, M.D. \& Guiry, G.M. 2019. AlgaeBase. World-wide electronic publication, National University of Ireland, Galway en http://www.algaebase.org; consultado el 7 de diciembre de 2019.

Graham, L.E. \& Wilcox, L.W. 2000. Algae. New Jersey (USA). Prentice-Hall. 640 p.

Greuter, W., McNeill, J., Barrie, F.R., Burdet, H.M., Demoulin, V., Filgueriras, T.S., Nicolson, D.H., Silva, P.C., Skog, J.E., Trethane, P., Turland, N.J. \& Haw ksorth, 
D.L. 2000. International Code of Botanical Nomenclature (Saint Louis Code). Koeltz Scitific Books, Königstein. 474 p.

Häder, D.P., Porst, M. \& Lebert, M. 2001. Photoinhibition in common Atlantic macroalgae measured on site in Gran Canaria. Helgol. Mar. Res. 55: 67-76.

Häder, D.P., Helbling, E.W., Williamson, C.E. \& Worrest, R.C. 2011. Effects of UV radiation on aquatic ecosystems and interactions with climate change. Photochem. Photobiol. Sci. 10: 242-260.

Hanelt, D. \& Figueroa, F.L. 2012. Physiological and photomorphogenic effects of light on marine macrophytes. In: Wiencke, C. and Bischof, K. (eds.). Seaweed Biology: novel insights into ecophysiology, ecology and utilization. p. 3-23.

Harb, T.B., NARdell, A. \& Chow, F. 2018. Physiological responses of Pterocladiella capillacea (Rhodophyta, Gelidiales) under two light intensities. Photosynthetica 56: 1093-1106.

Haroun, R.J., Gil-Rodríguez, M.C., Afonso-Carrillo, J. \& Wildpret de la Torre, W. 1984. Vegetación bentónica del roque de Los Órganos. Anales Biología 2: 107-117.

Haroun, R.J., Gil-Rodríguez, M.C., Díaz de Castro, J. \& Prud’homme van Reine, W.F. 2002. A checklist of the marine plants from the Canary Islands (central eastern Atlantic Ocean). Bot. Mar. 45: 139-169.

Hawnins, S.J., Evans, A.J., Firth, L.B., Genner, J., Herbet, R.J., Adams, L.C., Moore, P.J., Mieszkowska, N., Thompson, R.C., Burrows, M.T. \& Fenberg, P.B. 2016. Impacts and effects of ocean warming on intertidal rocky habitats. In: Lafftoley, D. and Baxer, J.M. (eds.) Explaining ocean warming: Causes, scale, effects and consequences. IPCC Assessments Reports: $147-176$.

Hommersand, M.H. \& Frederice, S. 1988. An investigation of cystocarp development in Gelidium pteridifolium with a revised description of the Gelidiales (Rhodophyta). Phycologia 27: 254-272.

Hurd, C.L., Harrison, P.J., Bischof, K. \& Lobban, C.S. 2014. Seaweed ecology and physiology. Cambridge University Press, Cambridge, UK. 551 p.

John, D.M., Prud'homme van Reine, W., Lawson G.W., Kostermans, T.B. \& Price, J.H. 2004. A taxonomic and geographical catalogue of the seaweeeds of the Western coast of Africa and adjacent islands. Nova Hedwigia, Beihefte. Germany. 139 p.

Juanes, J.A. \& Puentes, A. 1993. Differential reattachment capacity of isomorphic life history phases of Gelidium sesquipedale. Hydrobiol. 260/261: 139-144.

Krueger-Hadfield, S.A. \& Hoban, S.M. 2016. The importance of effective sampling for exploring the population dynamics of haploid-diploid seaweeds. J. Phycol. 52: 1-9.

Lawson, G.W. \& Norton, T.A. 1971. Some observations on littoral and sublittoral zonation at Teneriffe (Canary Islands). Bot. Mar. 14: 116-120.

Lawson, G.W., Woelkerling, W.J., Price, J.H., Prud'homme van Reine, W.F. \& John, D.M. 1995. Seaweeds of the western coast of tropical Africa and adjacent islands: critical assessment. IV. Rhodophyta (Florideae) 5. Genera P. Bull. Nat. Hist. Mus. Lond. (Bot.) 25: 99-122.

Lindgren, A., Bouza, N., Aberg, P. \& Sosa, P.A. 1998. Spatial and temporal variation in distribution of Gelidium canariensis, (Rhodophyta) from natural populations of the Canary Islands. J. Appl. Phycol. 10: 273-278. 
Maggs, C.A. \& Rico, J.M. 1991. A karyological demonstration of meiosis in Gelidium latifolium (Gelidiaceae, Rhodophyta) from Ireland. Phycologia 30: 487-494.

Martín, J.L., Bethencourt, J. \& Cuevas-Agulló, E. 2011. Evaluación del calentamiento global en Tenerife. Tendencias desde 1944 en las temperaturas máximas y mínimas anuales. Informe Técnico. Gobierno de Canarias, Agencia Canaria de desarrollo sostenible y cambio climático. $28 \mathrm{p}$.

Martínez, B., Afonso-Carrillo, J., Anadón, R., Araújo, R., Arenas, F., Arrontes, J., Bárbara, I., Borja, A., Díez, I., Duarte, L., Fernández, C., García Tasende, M., Gorostiaga, J.M., Juanes, J.A., Peteiro, C., Puente, A., Rico, J.M., Sangil, C., Sansón, M., Tuya, F. \& Viejo, R.M. 2015. Regresión de las algas marinas en la costa atlántica de la Península Ibérica y en las islas Canarias por efecto del cambio climático. Algas 49: 5-12.

McHugh, D.J. 2004. A guide to the seaweed industry. FAO Fisheries Technical Paper. Roma, FAO. $105 \mathrm{p}$.

Melo, R.A. \& Neushul, M. 1993. Life history and reproductive potential of the agarophyte Gelidium robustum in California. Hydrobiol. 260/261: 223-229.

Mercado, J.M., Figueroa, F.L. \& Niell, F.X. 1997. Method for estimating external carbonic anhydrase activity in macroalgae. J. Phycol. 33: 999-1006.

Mercado, J.M., Gordillo, F.J., Figueroa, F.L. \& Niell, F.X. 1998. External carbonic anhydrase and affinity for inorganic carbon in intertidal macroalgae. J. Exp. Mar. Biol. Ecol. 221: 209-220.

Mercado, J.M., Niell, F.X. \& Gil-Rodríguez, M.C. 2001. Photosynthesis might be limited by light, not inorganic carbon availability, in three intertidal Gelidiales species. New Phytologist 149: 431-439.

Montagne, C. 1840. Plantae Cellulares. In: Webb, P. and Berthelot, S. (eds.) Histoire naturelle des îles Canaries, Tome troisième. Deuxième partie: Phytographia canariensis. Sectio ultima. Bethune, París. 208 p.

Otaíza, R.D., Rodríguez, C.Y., Cáceres J.H. \& Sanhueza, A.G. 2018. Fragmentation of thalli and secondary attachment of fragments of the agarophyte Gelidium lingulatum (Rhodophyta, Gelidiales). J. Appl. Phycol. 30: 1921-1931.

Piccone, A. 1884. Crociera del Corsaro alle Isole Madera e Canarie del Capitano Enrico d'Albertis. Alghe. 60 p.

Piccone, A. 1886. Pugillo di Alghe Canariensi. Nouvo Giorn. Bot. Ital. 18: 119-121.

Pinedo, S. \& Afonso-Carrillo, J. 1994. Distribución y zonación de las algas marinas bentónicas en Puerto de la Cruz, Tenerife (Islas Canarias). Vieraea 23: 109-123.

Pinedo, S., Sansón, M. \& Afonso-Carrillo, J. 1992. Algas marinas bentónicas de Puerto de la Cruz (antes Puerto Orotava), Tenerife (Islas Canarias). Vieraea 21: 29-60.

Perrone, C., Felicini, G.P. \& Bottalico, A. 2006. The prostrate system of the Gelidiales: diagnostic and taxonomic importance. Bot. Mar. 49: 23-33.

Polifrone, M., Gil-Rodríguez, M.C., Domínguez-Álvárez, S., Stroobant, M. \& Viera-RoDRÍGUEZ, M.A. 2012. Reproductive phenology of three species of Gelidiales (Rhodophyta) in two macroalgal communities from Tenerife (Atlantic Ocean, Canary Islands, Spain). Anales del Jardin Botánico de Madrid 69: 247-252. 
Price, J.H., John, D.M. \& Lawson, G.W. 1988. Seaweeds of the western coast of tropical Africa and adjacent islands: a critical assessment. IV. Rhodophyta (Florideae) 2. Genera G. Bull. Br. Mus. Nat. Hist. (Bot.) 18: 195-273.

Quintano, E., Díez, I., Muguerza, N., Figueroa, F.L. \& Gorostiaga, J.M. 2017. Bed structure (frond bleaching, density and biomass) of the red alga Gelidium corneum under different irradiance levels. J. Sea Res. 130: 180-188.

Quintano, E., Díez, I., Muguerza, N., Figueroa F.L. \& Gorostiaga, J.M. 2018. Depth influence on biochemical performance and thallus size of the red alga Gelidium corneum. Mar. Ecol. e12478.

Quintano, E., Díez, I., Muguerza, N., Santolaria, A. \& Gorostiaga, J.M. 2015. Epiphytic flora on Gelidium corneum (Rhodophyta: Gelidiales) in relation to wave exposure and depth. Sci. Mar. 79: 479-486.

Quintano, E., Ganzedo, E., Díez, I., Figueroa, F.L. \& Gorostiaga, J. 2014. Solar radiation (PAR and UVA) and waer temperatura in relation to biochemical performance of Gelidium corneum (Gelidiales, Rhodophyta) in subtidal bottoms off the Basque coast. J. Sea Res. 83: 47-55.

Rancel, N. 2008. Morfología vegetativa y reproductora de Pterocladiela melanoidea (Gelidiales, Rhodophyta) en las Islas Canarias. Memoria Fase investigación DEA. Universidad de La Laguna. España. 50 p.

Rao, M.U. \& Kaliaperumal, N. 1983. Effects of environmental factor on the liberation of spores from some red algae of Visakhapatnam coast. J. Exp. Mar. Biol. Ecol. 70: 45-53.

Rao, M.U. \& Kaliaperumal, N. 1987. Diurnal periodicity of spore-shedding in some red algae of Visakhapatnam coast. J. Exp. Mar. Biol. Ecol. 106: 193-199.

RaVEn, J.A. 1997. Inorganic carbon acquisition by marine autotrophs. Ad. Bot. Res. 27: 85-209.

Reyes, J., Sansón, M. \& Afonso-Carrillo, J. 1993. Notes on some interesting marine algae new from the Canary Islands. Crypt. Bot. 4: 50-59.

Reyes, J., Sansón, M. \& Afonso-Carrillo, J. 1994. Algas marinas bentónicas de El Médano, S Tenerife (Islas Canarias). Vieraea 23: 15-42.

Reyes, J., Sansón, M. \& Afonso-Carrillo, J. 2005. Flora y vegetación marina. Algas y sebas. En: Rodríguez-Delgado, O. (ed.) Patrimonio Natural de la isla de Fuerteventura. Centro de la Cultura Popular Canaria, Tenerife. pp. 117-140.

Rico, J.M., Domínguez-Álvarez, S., Morales-Pérez, C.E. \& Gil-Rodríguez, M.C. 2005. Variability in sporangial types in Gelidium canariense (Gelidiaceae, Rhodophycota). Revista de la Academia Canaria de Ciencias 17: 19-25.

Rico, J.M., Freshwater, D.W., Norwood, K.G. \& Guiry, M.D. 2002. Morphology and systematics of Gelidiella tenuissima (Gelidiales, Rhodophyta) from Gran Canaria (Canary Islands, Spain). Phycologia 41: 463-469.

Rodríguez, M., Pérez, Ó., Monterroso, Ó., Ramos, E., Riera, R., Sánchez, J., Sacramento, A., Gil-Rodríguez, M.C., Cruz, A., Morales, T., Sangil, C. \& Domínguez, S. 2008 a. Estudio de la distribución y tamaño de población de la especie Gelidium arbuscula Bory de Saint-Vincent ex Børgesen, 1927 en Canarias. C.I.M.A. Informe Técnico 31. 140 p.

Rodríguez, M., Pérez, Ó., Monterroso, Ó., Ramos, E., Riera, R., Sánchez, J., Sacramento, A., Gil-Rodríguez, M.C., Cruz, A., Morales, T., Sangil, C. \& Domínguez, S. 2008b. Estudio de la distribución y tamaño de población de la especie Gelidium canariense (Gru- 
now) Seoane Camba ex Haroun, Gil-Rodríguez, Díaz de Castro \& Prud'homme van Reine, 2002 en Canarias. CIMA. Informe Técnico 31.96 p.

Sangil, C., Sansón, M. \& Afonso-Carrillo, J. 2003. Algas marinas de La Palma (islas Canarias): novedades florísticas y catálogo insular. Vieraea 31: 83-119.

Sangil, C., Sansón, M. \& Afonso-Carrillo, J. 2004. Zonación del fitobentos en el litoral nordeste y este de La Palma (islas Canarias). Revista de la Academia Canaria de Ciencias 3-4: 279-300.

Sansón, M., Sangil, C., Orellana, S. \& Afonso-Carrillo, J. 2013. Do the size shifts of marine macroalgae match the warming trends in the Canary Islands? Libro de Resúmenes, XIX Simposio de Botánica Criptogámica p. 104.

Santelices, B. 1977. A taxonomic review of Hawaiian Gelidiales (Rhodophyta). Pacific Science 31: 61-84.

Santelices, B. 1987a. The wild harvest and culture of the economically important species of Gelidium in Chile. In: Doty, D.S., Caddy, J.F., \& Santelices, B. (eds.) FAO Fisheries technical paper -281 Food and agriculture organization of the United Nations. Rome, Italy. 21 p.

Santelices, B. 1987b. Métodos alternativos para la propagación y el cultivo de Gelidium en Chile central. En: Verreth, J.A., Carillo, M., Zanuy, S. \& Huisman, E.A. (eds.) Investigación Acuícola en América Latina. Centre for Agricultural Publishing and documentation (Pudoc) Wageningen, Netherlands. p. 349-366.

SAntelices, B. 1997. The spermatangial sorus of Gelidiella acerosa (Gelidiellaceae, Gelidiales). In: Abbot, I.A (ed.) Taxonomy of economic seaweeds, with reference to some Pacific and Western Atlantic species VI. California Sea Gran College System, Report T-040, Universidad de California, California EE.UU. p. 77-87.

Santelices, B. 2004. Parviphycus, a new genus in the Gelidiellaceae (Gelidiales, Rhodophyta). Cryptogamie, Algol. 25: 313-326.

Santelices, B. \& Hommersand, M. 1997. Pterocladiella, a new genus in the Gelidiaceae (Gelidiales, Rhodophyta). Phycologia 36: 114-119.

Santos, R. \& Duarte, P. 1996. Fecundity, spore recruitment and size in Gelidium sesquipedale (Gelidiales, Rhodophyta). Hydrobiol. 326/327: 223-228.

Sauvageau, C. 1912. A propos des Cystoseira de Banylus et Guéthary. Bull. Stn. Biol. Arcachon 14: $133-556$.

Scariot, L.A., Rover, T., Simioni, C., Horta, P., Oliveira, E. \& Bouzon, Z.L. 2012. Effects of UV-B radiation on Gelidium floridanum (Rhodophyta, Gelidiales): germination of tetraspores and early sporeling development. J. Appl. Phycol. 25: 537-544.

Schmidt, E.C., Kreusch, M., Felix, M.L., Pereira, D., Costa, G.B., Simioni, C., Ouriques, L.C., Farias-Soares, F., Steiner, N., Chow, F. et al. 2015. Effects of Ultraviolet (UVA+UVB) and copper on the morphology, ultrastructural organization and physiological responses of the red alga Pterocladiella capillacea. Photochem. Photobiol. 91: 359-370.

Scrosati, R. \& Servière-Zaragoza, E. 2000. Ramet dynamics for the clonal seaweed Pterocladiella capillacea (Rhodophyta): a comparison with Chondrus crispus and with Mazzaella cornucopiae (Gigartinales). J. Phycol. 36: 1061-1068.

Seonne-Camba, J. 1977. Sur une nouvelle espèce de Gelidiella trouvée aux Iles Canaries: Gelidiella tinerfensis nov. sp. Soc. Phycol. de France Bull. 22: 127-134. 
Seonne-Camba, J. 1979. Sobre algunas gelidiáceas nuevas o poco conocidas de las costas españolas. Acta Bot. Malac. 5: 99-112.

Simioni, C., Rover, T., Schmidt, C., Felix, M.R., Polo, L.K., dos Santos, R., Costa, G.B., Kreusch, M., Pereira, D.T., Ouriques, C. \& Bouzon, Z.L. 2014a. Effects of brefeldin A on the endomembrane system and germ tubeformation of the tetraspore of Gelidium floridanum (Rhodophyta, Florideophyceae). J. Phycol. 50: 577-586.

Simioni, C., Schmidt, E.C., Felix, M.R., Polo, L.K., Rover, T., Kreusch, M., Pereira, D.T., Chow, F., Ramlov, F., Maraschin, M. \& Bouzon, Z.L. 2014b. Effects of ultraviolet radiation (UVA+UVB) on young gametophytes of Gelidium floridanum: growth rate, photosynthetic pigments, carotenoids, photosynthetic performance and ultrastructure. Photochem. Photobiol. 90: 1050-1060.

Sosa, P.A \& García-Reina, G. 1992. Genetic variability and differentiation of sporophytes and gametophytes in populations of Gelidium arbuscula (Gelidiaceae: Rhodophyta) determined by isozyme electrophoresis. Mar. Biol. 113: 679-688.

Sosa, P.A. \& García-Reina, G. 1993. Genetic variability of Gelidium canariensis (Rhodophyta) determined by isozyme electrophoresis. J. Phycol. 29: 118-124.

Sosa, P.A., Valero, M., Batista, F.J. \& González-Pérez, M.A. 1998. Genetic structure of Gelidium species. A re-evaluation of results. J. App. Phycol. 10: 279-284.

Stroobant, M., Polifrone, M. \& Viera-Rodríguez, M.A. 2014. Reproductive pattern of Pterocladiella capillacea (Gelidiales, Rhodophyta) at Canary Islands (Spain, Atlantic Ocean). J. Coast. Life Med. 2: 769-772.

Suneson, S. 1982. The culture of bisporangial plants of Dermatolithon litorale (Suneson) Hamel et Lemoine (Rhodophyta, Corallinaceae). Br. phycol. J. 17: 107-116.

Taskin, E. \& Wynne, M.J. 2013. Proposal of Gelidium serra (S.G. Gmel.) comb. Nov. to replace Gelidium bipectinatum G.Furnari (Rhodophyta). Webbia: J. Plant. Taxon. Geograph. 68: 21-23.

Tronchin, E.M. \& Freshwater, D.W. 2007. Four Gelidiales (Rhodophyta) new to southern Africa, Aphanta pachyrrhiza gen. et sp. nov., Gelidium profundum sp. nov., Pterocladiella caerulescens and P. psammophila sp. nov. Phycologia 46: 325-348.

Tronchin, E.M., Freshwater, D.W., Bolton, J.J. \& Anderson, R.J. 2002. A reassessment and reclassification of species in the genera Onikusa Akatsuka and Subria J. Argardh ex Endlicher (Gelidiales, Rhodophyta) based on molecular and morphological data. Bot. Mar. 45: 548-558.

Verbruggen, H., Maggs, C.A., Saunders, G.W., Le Gall, L., Yoon, H.S. \& De Clerck, O. 2010. Data mining approach identifies research priorities and data requirements for resolving the red algal tree of life. BMC Evol. Biol. 10: 1-16.

Vickers, A. 1896. Contribution à la flore algologique des Canaries. Ann. Sci. Nat. (Bot.) 4: 293-306.

Wildpret, W., Gil-Rodríguez, M.C. \& Afonso-Carrillo, J. 1987. Evaluación cuantitativa y cartografía de los campos de algas y praderas de fanerógamas marinas del litoral canario. Consejería de Agricultura y Pesca, Gobierno de Canarias. Informe técnico.

Woelkerling, W.J. 1990. An introduction. In: Cole, K.M. and Sheath, R.G. (eds.) Biology of the Red Algae. Cambridge University Press. Cambridge, UK. pp. 1-6.

Woelkerling, W.J., Furnari, G., Guardia, R. \& Perrone, C. 2018. Gelidiella tinerfensis Seoane-Camba (Gelidiaceae, Rhodophyta): nomenclatural validity, tipification and taxonomic status. Notulae algarum 80: 1-5. 
Yang, E.C., Boo, S.M., Bhattacharya, D., Saunders, G.W., Knoll, A., Fredericq, S., Graf, L. \& Yoon, H.S. 2016. Divergence time estimates and the evolution of major lineages in the florideophyte red algae. Sci. Rep. 6: 21361.

Yang, E.C., Kim, K.M., Kim, S.Y., Lee, J.M., Boo, G.H., Lee, J.H., Nelson, W.A., YI, G., SchMidT, W.E., FredericQ, S. et al. 2015. Highly conserved mitochondrial genomes among multicellular red algae of the Florideophyceae. Genome Biol. Evol. 7: 2394-2406.

Yang, S., Doolittle, R.F. \& Bourne, P.E. 2005. Phylogeny determined by protein domain content. PNAS 102: 373-378.

Yoon, H.S., Müller, K.M., Sheath, R.G., Ott, F.D. \& Bhattacharya, D. 2006. Defining the major lineages of red algae (Rhodophyta). J. Phycol. 42: 482-492.

Yoon, H.S., Nelson, W., Lindstrom, S.C., Boo, S.M., Pueschel, C., Qiu, H. \& Bhattacharya, D. 2016. Rhodophyta. In: Archibald, J.M., Simpson, A.G.B., Slamovits, C.H., Margulis, L., Melkonian, M., Chapman, D.J. and Corliss, J.O. (eds.) Handbook of the Protists. Springer International Publishing Switzerland. 45 p.

Yoon, H.S., Zuccarello, G.C. \& Bhattacharya. 2010. Evolutionary history and taxonomy of red algae. In: Seckbach, J. \& Chapman, D.J. (eds.) Red algae and genomic age. Springer Dordrecht Deidelberg London New York. pp. 27-42. 


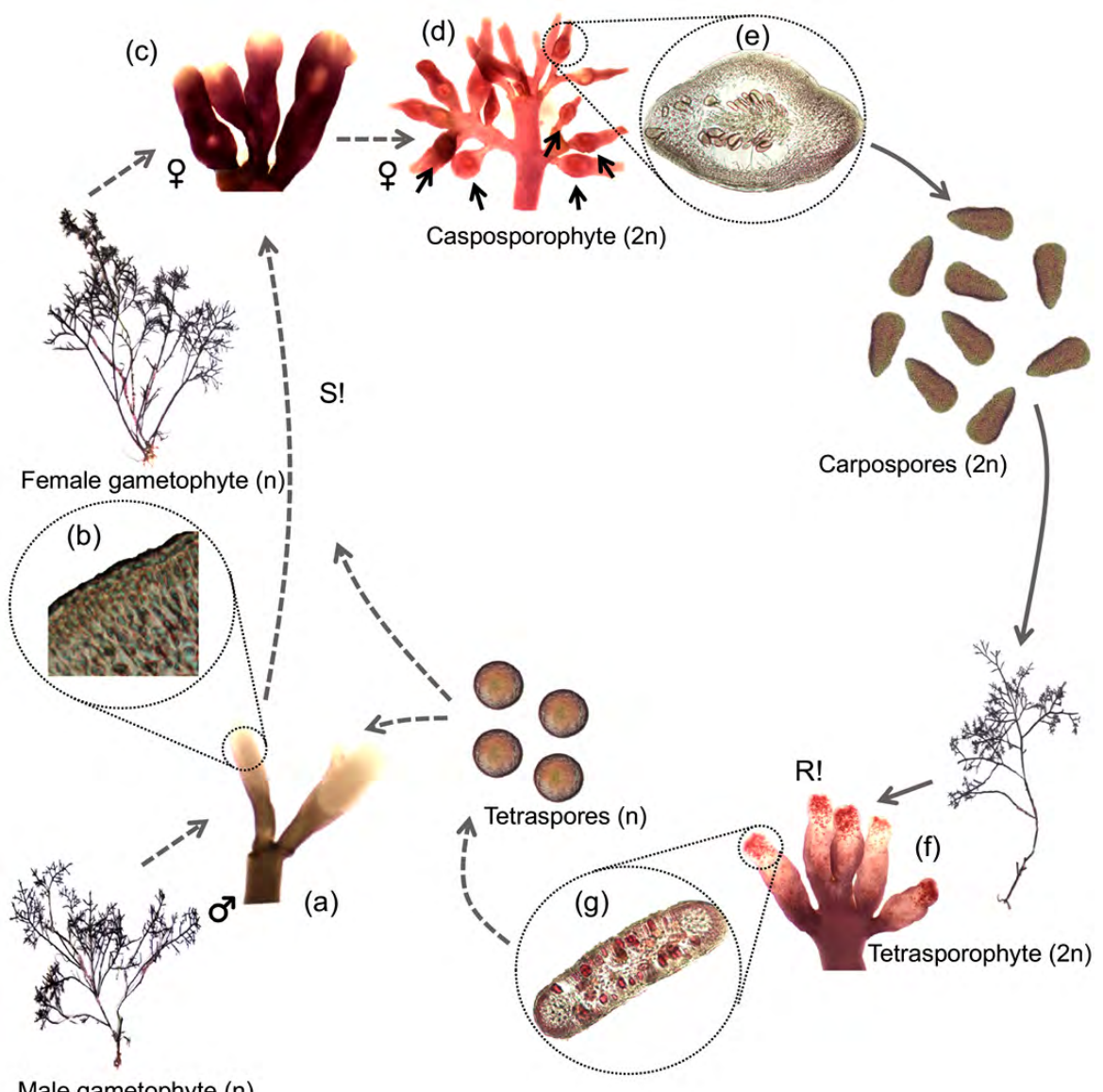
tetrasporangia (f) located in sori at ends of last order branches and immerse in the cortex (g). Meiosis (R!) occurs in each tetrasporangium to generate four haploid (n) tetraspores leaving empty cells when release. Dashed line indicates the haploid phases and continuous line indicates diploid phases of the cycle. Images obtained and adapted from Alfonso et al. (2017). 
1

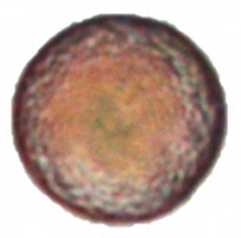

3

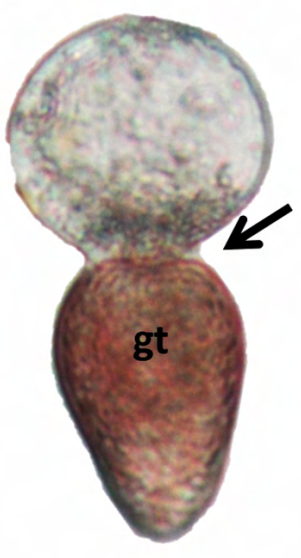

2

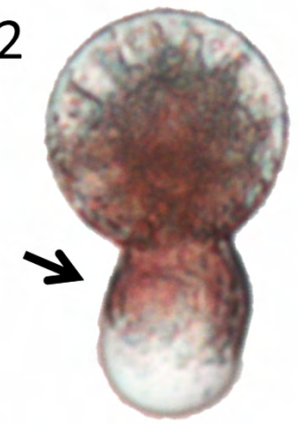

4

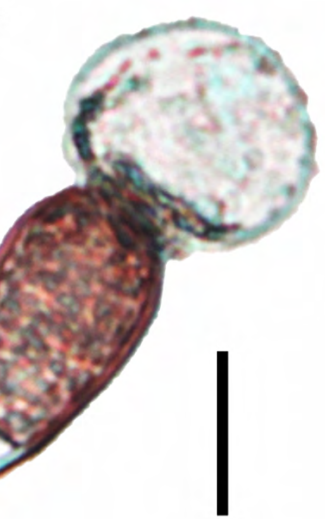

Figure 2. Gelidium-type germination pattern. (1) tetraspore immediately after release and settlement still lacking cell wall. ( 2 and 3 ) Between 2 to 4 hours after release and attachment of the spore: (2) germination tube begin to develop from the protoplasm content in migration (red color) and germination tube is protrude (arrow); (3) the germination tube is surrounded by a cell wall and separated from the original spore (arrow). (4) 24 hours after tetraspore release. Multicellular organism showing elongate distal cell (dc) and primary rhizoid (arrow). Scale $20 \mu \mathrm{m}$. Adapted from Alfonso et al. (2018). 

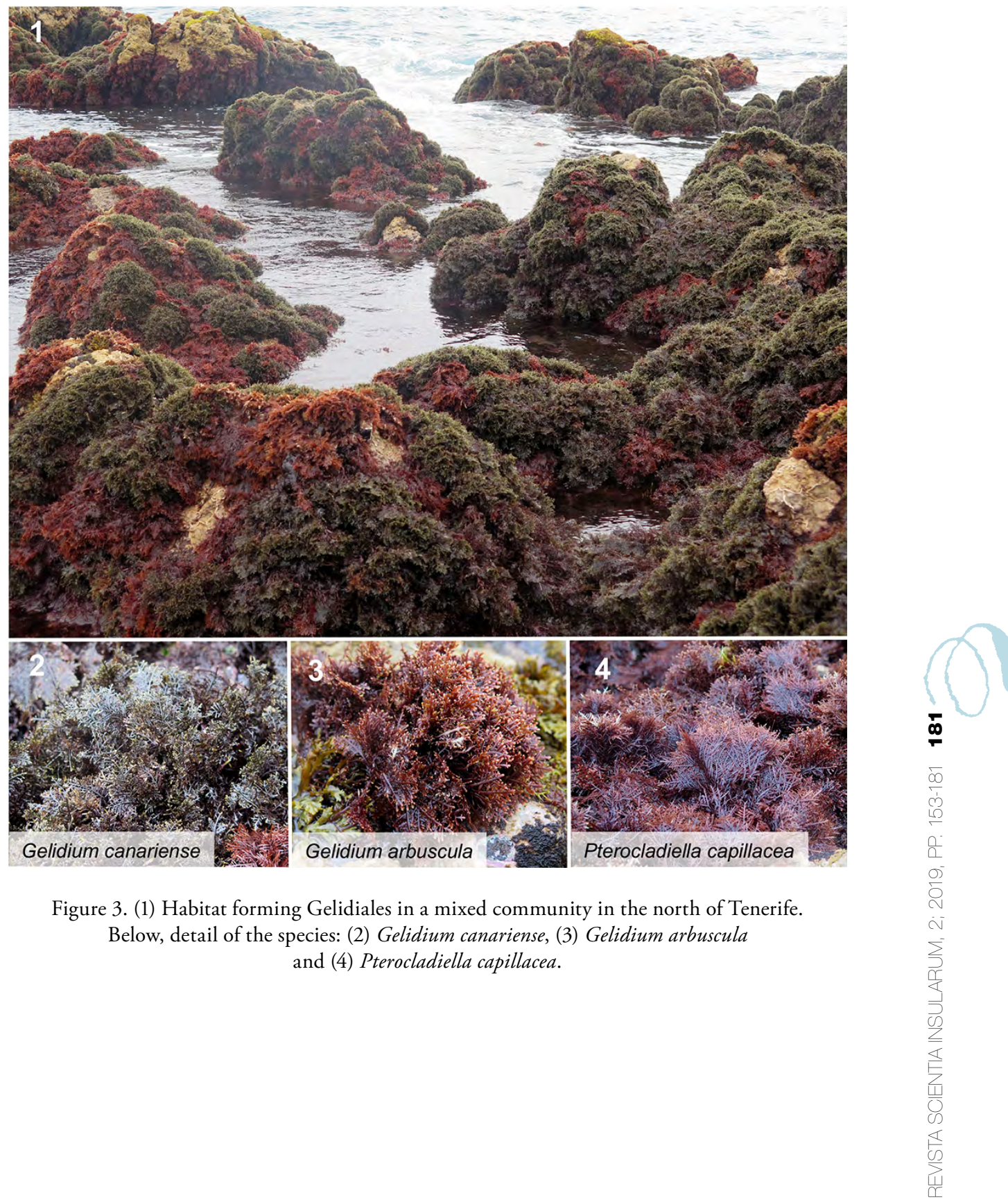